\title{
Imaging characteristics and surgical treatment of invasive meningioma
}

\author{
WEINA HOU ${ }^{1}$, YONGQIAN MA ${ }^{2}$, HONGSHUN XING ${ }^{2}$ and YUEHUI YIN ${ }^{1}$ \\ Departments of ${ }^{1}$ Radiology and ${ }^{2}$ Neurosurgery, Weifang People's Hospital, Weifang, Shandong 261041, P.R. China
}

Received August 1, 2016; Accepted February 3, 2017

DOI: $10.3892 / \mathrm{ol} .2017 .5833$

\begin{abstract}
In order to provide an effective way to prevent or substantially delay the recurrence of invasive meningioma, and improve the curative effect of surgical treatment, we collected and analyzed the clinical manifestations, pathological features, preoperative imaging characteristics as well the data obtained during the surgical treatment of invasive meningioma. From February 2014 to February 2016, 59 patients with invasive meningioma were enrolled in this study. Invasive meningioma was confirmed in all patients by operation. Information about clinical manifestations, pathological features, preoperative imaging and surgical treatment were collected and analyzed. After surgery, pathological specimens were collected, and cases were confirmed as invasive meningioma by pathological examination. The course of disease ranged from 15 days to 7 years (average, 13.2 months). We used World Health Organization (WHO) criteria for classification of meningioma in the nervous system tumors as our reference. Symptoms were as follows: Intracranial hypertension (29 cases), cranial nerve dysfunction (10 cases), epilepsy (11 cases) and other symptoms (9 cases). We had 56 cases of WHO grade I; 6 cases of WHO grade II and 7 cases of WHO grade III. Surgical removal was: Simpson grade I (56 cases), Simpson grade II (2 cases), Simpson grade III and above (56 cases). We used before surgery imaging data to formulate our surgical plan. In general, during surgeries we did not proceed to complete resection, because in the majority of cases, some key structures were invaded and meningioma was very deep and any attempt for total resection could easily lead to significant damage to these structures.
\end{abstract}

Correspondence to: Dr Yuehui Yin, Department of Radiology, Weifang People's Hospital, 151 Guangwen Street, Kuiwen, Weifang, Shandong 261041, P.R. China

E-mail: yin_yuehui1@163.com

Key words: invasive meningioma, imaging features, pathology, surgical treatment

\section{Introduction}

Invasive meningioma is a common neoplasm of central nervous system, which can infiltrate adjacent tissues (dura mater, arachnoid membrane, vascular space and skull) without atypical hyperplasia $(1,2)$. Meningioma comprises of $24-30 \%$ of primary intracranial neoplasm and commonly affects females during middle or later adult life $(3,4)$. Primary intracranial meningioma usually arises in proximity to meninges, particularly in the parasagittal meninges, falx cerebri and sphenoid sphenoid ridges (3). Currently, various methods are employed for diagnosis and evaluation of meningioma $(5,6)$. Computed tomography $(\mathrm{CT})$ and magnetic resonance imaging (MRI) have become useful diagnostic tools for accurately definition. In addition, CT and MRI imaging can also be used to determine whether meningioma is invasive or not. Invasive growth substantially increases the risk of recurrence (7-9).

In order to provide an effective way to prevent or substantially delay the recurrence of invasive meningioma, and improve the curative effect of surgical treatment, we collected and analyzed the clinical manifestations, pathological features, preoperative imaging characteristics as well the data obtained during the surgical treatment of invasive meningioma. In most cases, postoperative radiotherapy was needed to delay, or even prevent the recurrence.

\section{Materials and methods}

General materials. From February 2014 to February 2016, 59 patients with invasive meningioma were enrolled in this study. Presence of invasive meningioma was confirmed by operation. There were 43 males and 16 females (gender ratio, 2.3:1), and the age range was from 45 to 75 years (average, 55.3 years). The course of disease ranged from 15 days to 7 years (average, 13.2 months). There were 4 cases with multiple symptoms and 3 cases suffered from recurrence.

Clinical data and methods. We used World Health Organization (WHO) criteria for classification of meningioma in the nervous system tumors as our reference (10). There are 3 grades in WHO classification: Benign (grade I), atypical (grade II), and anaplastic (grade III). All situations during the operation were recorded and scope of surgical resection was determined according to Simpson classification (11). 


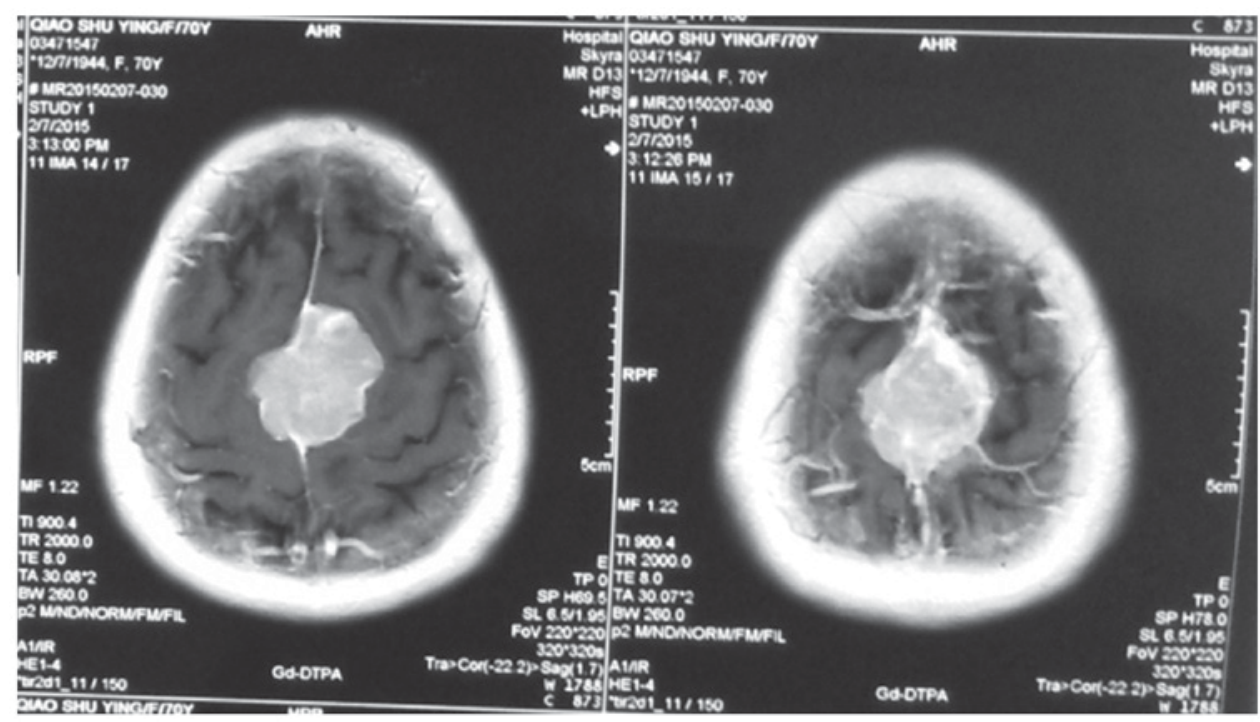

Figure 1. Meningioma was located beside the superior sagittal sinus, dural tail sign and false envelope were seen.

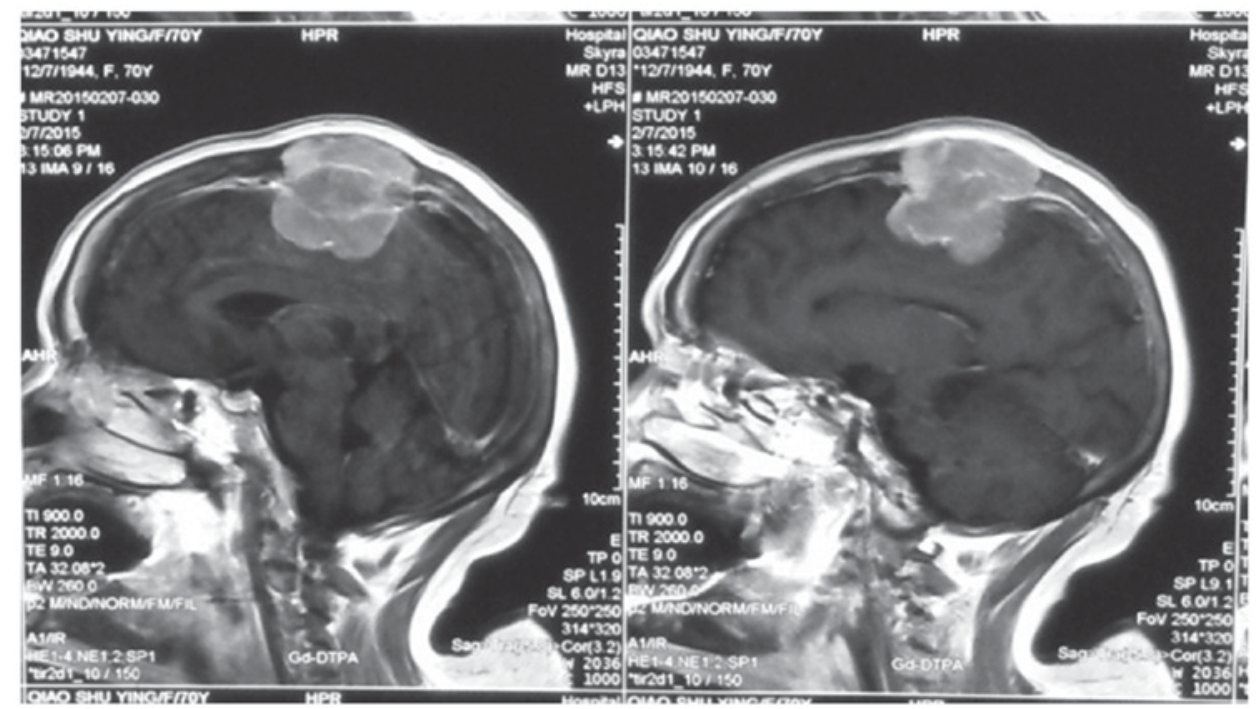

Figure 2. Meningioma invaded the skull, superior sagittal sinus, scalp and other structures.

The selection criteria. The selection basis was as follows: i) During the operation, the tumor surrounding tissues were visibly invaded by cancer cells; ii) pathological examination was performed on the tumor surrounding tissues, and presence of tumor cell infiltration was confirmed; and iii) results obtained from imaging examinations revealed that tumor cells were invading the adjacent blood vessels and adjacent nerves. Patients who complied with (i) and/or (ii) were selected and (iii) was regarded as the standard. This study was approved by the Ethics Committee of Weifang People's Hospital. Signed written informed consents were obtained from all participants before the study.

Clinical manifestations. Ten patients suffered from cranial nerve dysfunction with symptoms such as ocular motility disorders, visual disturbance and facial numbness. Twenty-nine patients suffered from intracranial hypertension with symptoms such as dizziness, headache and vomiting. Eleven patients suffered from epilepsy and paroxysmal tic. Nine patients were found, for first time, to have invasive meningioma after examination or postoperative re-examination.

Imaging examinations. All patients agreed to undergo skull MRI and/or CT scan examinations. MRI results showed that, on T1 weighted images, meningioma was mainly manifested as the equal signal (the majority) and low signal (the minority). High signal revealed that, on T2 weighted images, 'pseudocapsule sign' was seen around the tumor, significantly intensified and dural tail sign appeared after enhancement (Figs. 1-3).

Contrast-enhanced MRI scan results showed that the phenomenon of dural tail sign appeared in 41 cases. The results of cranial CT scan showed middle-density masses or slight hyper-density masses in all the patients, low-density masses with different sizes were found in some patients, significant and enhanced intensification appeared after imaging enhancement. Edema area was detected around the meningioma. 
Table I. The classification and location of invasive meningioma.

\begin{tabular}{|c|c|c|c|c|}
\hline \multirow[b]{2}{*}{ The area of tumors } & \multirow[b]{2}{*}{ Cases } & \multicolumn{3}{|c|}{ Pathological classification } \\
\hline & & $\begin{array}{l}\text { WHO } \\
\text { grade I }\end{array}$ & $\begin{array}{l}\text { WHO } \\
\text { grade II }\end{array}$ & $\begin{array}{l}\text { WHO } \\
\text { grade III }\end{array}$ \\
\hline Cerebral convexity & 18 & 18 & 0 & 0 \\
\hline $\begin{array}{l}\text { Surrounding area of } \\
\text { parasagittal region of } \\
\text { cerebral falx }\end{array}$ & 17 & 17 & 0 & 0 \\
\hline $\begin{array}{l}\text { Surrounding area of } \\
\text { transverse sinus } \\
\text { and sigmoid sinus }\end{array}$ & 8 & 8 & 0 & 0 \\
\hline $\begin{array}{l}\text { Large blood and } \\
\text { vessels }\end{array}$ & 4 & 2 & 2 & 0 \\
\hline Skull & 6 & 6 & 0 & 0 \\
\hline Cavernous sinus & 4 & 4 & 0 & 0 \\
\hline Periorbital region & 1 & 1 & 0 & 0 \\
\hline $\begin{array}{l}\text { The infiltration of } \\
\text { brain }\end{array}$ & 1 & 0 & 0 & 1 \\
\hline In total & 59 & 56 & 2 & 1 \\
\hline
\end{tabular}

Table II. The relationship between the invasive region and surgical resection of meningioma.

\begin{tabular}{|c|c|c|c|c|}
\hline \multirow[b]{2}{*}{$\begin{array}{l}\text { The invasive region } \\
\text { of meningioma }\end{array}$} & \multirow[b]{2}{*}{ Cases } & \multicolumn{3}{|c|}{ Surgical classification } \\
\hline & & $\begin{array}{l}\text { Simpson } \\
\text { grade I }\end{array}$ & $\begin{array}{c}\text { Simpson } \\
\text { grade II }\end{array}$ & $\begin{array}{l}\text { Simpson } \\
\text { grade III }\end{array}$ \\
\hline Cerebral convexity & 18 & 18 & 0 & 0 \\
\hline $\begin{array}{l}\text { Surrounding area of } \\
\text { parasagittal region } \\
\text { of cerebral falx }\end{array}$ & 17 & 4 & 12 & 1 \\
\hline $\begin{array}{l}\text { Surrounding area of } \\
\text { transverse sinus and } \\
\text { sigmoid sinus }\end{array}$ & 8 & 2 & 6 & 0 \\
\hline Skull & 6 & 3 & 3 & 0 \\
\hline Cavernous sinus & 4 & 0 & 2 & 2 \\
\hline $\begin{array}{l}\text { Large blood and } \\
\text { vessels }\end{array}$ & 4 & 0 & 1 & 3 \\
\hline Periorbital region & 1 & 0 & 1 & 0 \\
\hline $\begin{array}{l}\text { The infiltration of } \\
\text { brain }\end{array}$ & 1 & 1 & 0 & 0 \\
\hline In total & 59 & 56 & 25 & 6 \\
\hline
\end{tabular}

Before surgery, all patients underwent imaging examination. The invasion of the organizational structure around the tumor that was revealed by MRI and/or CT scan were used as the basis of imaging invasiveness. The sign of invasiveness is the presence of invasion in exterior structure and the wrapping of important blood vessels including large blood vessels (Table I). Meningioma was observed in a variety
Table III. The relationship between imaging characteristics and pathological classification.

\begin{tabular}{lccc}
\hline & \multicolumn{3}{c}{ Pathological classification } \\
\cline { 2 - 4 } $\begin{array}{l}\text { Imaging } \\
\text { characteristics }\end{array}$ & $\begin{array}{c}\text { WHO } \\
\text { grade I }\end{array}$ & $\begin{array}{c}\text { WHO } \\
\text { grade II }\end{array}$ & $\begin{array}{c}\text { WHO } \\
\text { grade III }\end{array}$ \\
\hline $\begin{array}{l}\text { The edema around } \\
\text { meningioma }\end{array}$ & 34 & 6 & 7 \\
$\begin{array}{l}\text { The invasion of } \\
\text { venous sinus }\end{array}$ & 17 & 0 & 0 \\
$\begin{array}{l}\text { The change of bone } \\
\text { The brain tumor } \\
\text { interfaces }\end{array}$ & 9 & 0 & 2 \\
$\begin{array}{l}\text { The invasion of } \\
\text { blood and vessels } \\
\begin{array}{l}\text { The invasion of } \\
\text { exterior structure }\end{array}\end{array}$ & 4 & 6 & 6 \\
\hline
\end{tabular}

of areas such as cerebral convexity (18 cases), parasagittal region (17 cases), tentorium of cerebellum (10 cases), cerebellar hemisphere (5 cases), CPA (3 cases), petroclival region ( 2 cases), olfactory sulcus (1 case) and sphenoid ridge (1 case).

\section{Results}

Pathological examination. Pathological examination found 56 cases in WHO grade I (10). There were 20 cases of meningioma of mixed cell type, 11 cases of meningioma of meningothelial type, 9 cases of fibroblastic meningioma, 5 cases of angiomatous meningioma. We had 2 cases of WHO grade II with 1 case of meningioma of clear cell type and 1 case of meningioma of atypical meningioma. Also we had one case of anaplastic meningioma (WHO grade III).

The invasive region of meningioma. During the surgeries we found out that meningioma was invading other regions, such as cerebral convexity (18 cases), area surrounding the parasagittal region (17 cases), area surrounding transverse sinus and sigmoid sinus ( 8 cases), skull (6 cases), large blood vessels ( 4 cases), cavernous sinus ( 4 cases) and periorbital region (1 case). Brain tissues around the tumor were collected for pathological examination and results showed that there was 1 case of the infiltration of brain. According to the region invaded by the tumor, patients were divided into 3 grades: i) Simpson grade I (the invasive region was cerebral convexity); ii) Simpson grade II (the invasive region was venous sinus, and tumor invaded large blood vessels and cavernous sinus); and iii) Simpson grade III (Table II).

Imaging examination. During the CT and MRI examinations, we clearly observed organizational structures around the tumor; structures such as edema around meningioma (47 cases), venous sinus invasion (17 cases), changes in bone structure (11 cases), brain tumor interfaces (16 cases), 


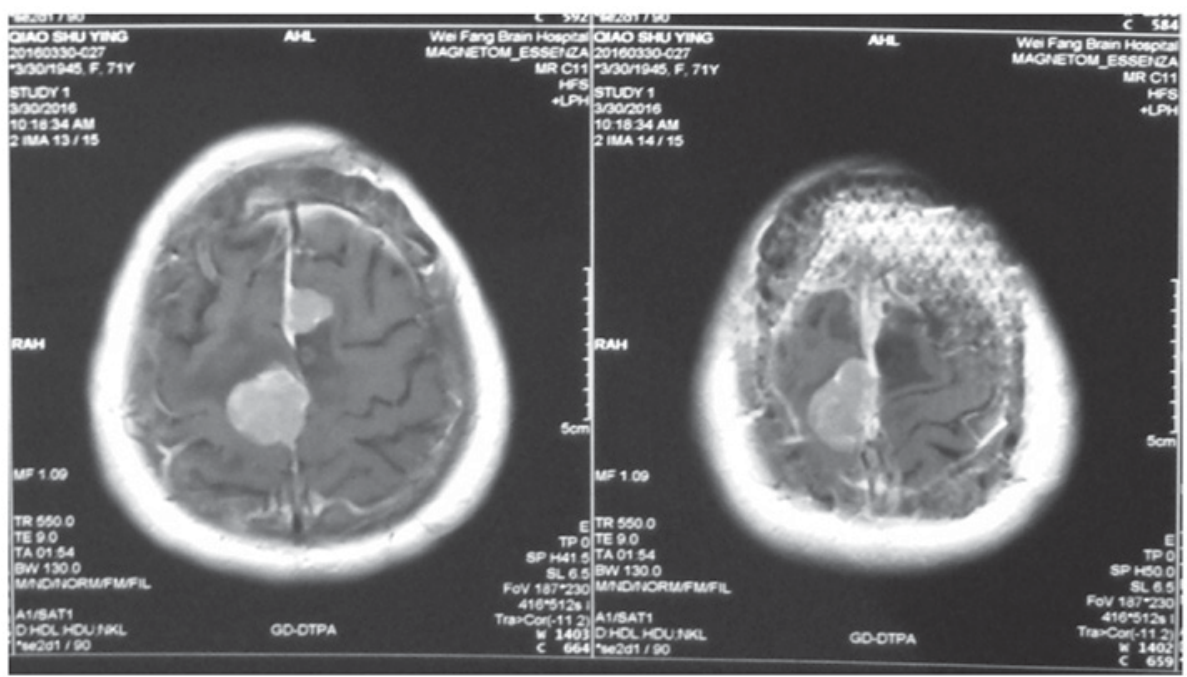

Figure 3. The recurrence of meningioma after surgery.

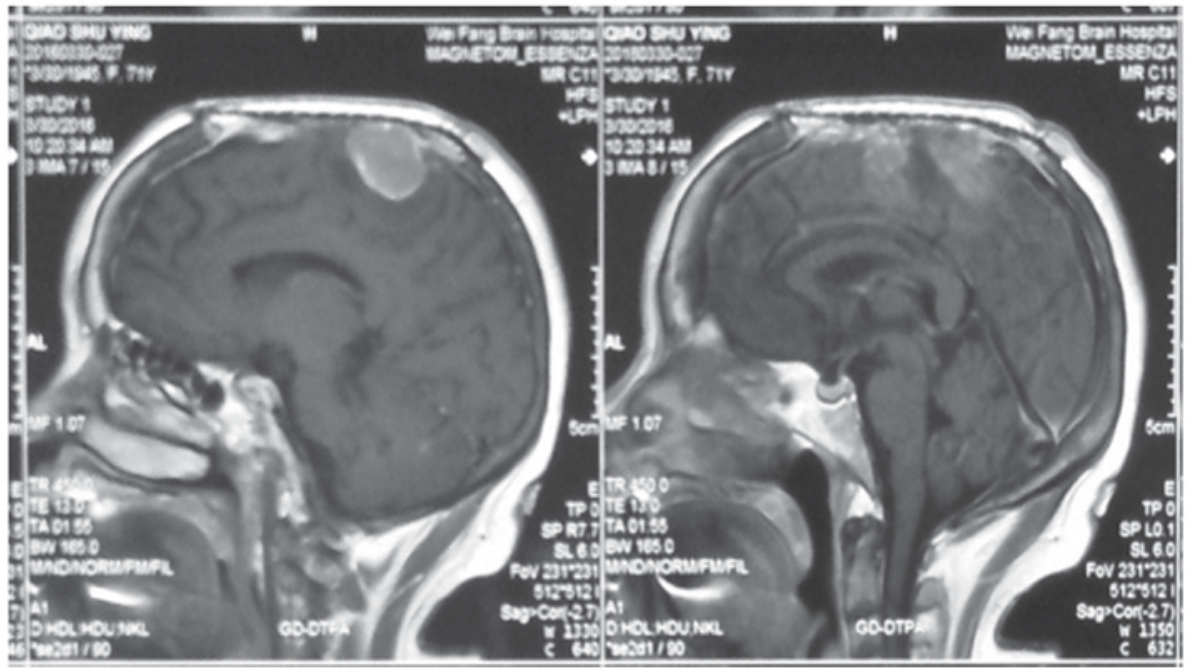

Figure 4. The recurrence of meningioma after surgery.

Table IV. The relationship between imaging manifestations and surgical resection.

\begin{tabular}{|c|c|c|c|c|c|}
\hline \multirow[b]{2}{*}{$\begin{array}{l}\text { The invasive region } \\
\text { of meningioma }\end{array}$} & \multirow[b]{2}{*}{ Cases } & \multicolumn{3}{|c|}{ Surgical classification } & \multirow[b]{2}{*}{$\begin{array}{l}\text { The invasive cases shown by } \\
\text { imageological examination }\end{array}$} \\
\hline & & $\begin{array}{c}\text { Simpson } \\
\text { grade I }\end{array}$ & $\begin{array}{c}\text { Simpson } \\
\text { grade II }\end{array}$ & $\begin{array}{l}\text { Simpson } \\
\text { grade III }\end{array}$ & \\
\hline Cerebral convexity & 18 & 18 & 0 & 0 & 8 \\
\hline $\begin{array}{l}\text { Surrounding area of } \\
\text { parasagittal region of } \\
\text { cerebral falx }\end{array}$ & 17 & 4 & 12 & 1 & 11 \\
\hline $\begin{array}{l}\text { Surrounding area of } \\
\text { transverse sinus and } \\
\text { sigmoid sinus }\end{array}$ & 8 & 2 & 6 & 0 & 6 \\
\hline Skull & 6 & 3 & 3 & 0 & 3 \\
\hline Large blood and vessels & 4 & 0 & 1 & 2 & 4 \\
\hline Cavernous sinus & 4 & 0 & 2 & 3 & 4 \\
\hline Periorbital region & 1 & 0 & 1 & 0 & 1 \\
\hline The infiltration of brain & 1 & 1 & 0 & 0 & 0 \\
\hline In total & 59 & 56 & 25 & 6 & 37 \\
\hline
\end{tabular}


blood vessels invasion (4 cases) and exterior structure invasion (1 case) (Figs. 1-4).

Other imaging characteristics such as nodular tumors (15 cases), tumors with cystic necrotic area (8 cases) and tumors with unclear border (16 cases) were also observed (Tables III and IV).

\section{Discussion}

Brain tumors are divided into primary and secondary tumors. The most common sites for primary tumors are cranial nerve and meninx. Several tissues have been reported as the origin of brain tumor and among them, the most common benign brain tumor is meningioma which accounts for $20 \%$ of all brain tumors $(12,13)$. Invasive meningioma can invade neighboring tissues. Brain tumors are slow growing and have a prolonged latency. The most common malignant brain tumor is glioma with characteristics such as fast growth, easy recurrence and high mortality rate $(14,15)$.

Clinical manifestations of invasive meningioma are similar to those of benign meningioma, the main symptoms are intracranial hypertension and chronic and progressive symptoms of brain damage $(16,17)$. Our results demonstrated that the most common symptoms among our patients were intracranial hypertension (29 cases), cranial nerve dysfunction (10 cases) and epilepsy (11 cases).

In most cases, the invasive meningiomas were located in supratentorial region. The most common invasion area was cerebral convexity and the area surrounding parasagittal region (35 cases or 59.3\%). The secondary invasive area were the areas surrounding the transverse sinus and sigmoid sinus (8 cases), followed by internal carotid artery, optic nerve and sponge antrum (4 cases), and finally the basilar artery and posterior cranial fossa cranial nerve (4 cases) (Tables I and II). These results were consistent with the results obtained in previous studies (18).

Prior studies revealed that pathological characteristics and classification of meningioma was closely related to the risk of tumor recurrence (19). The biological mechanisms underlying brain-invasive growth in meningioma are not completely understood. The invasive mechanism of invasive meningioma may be linked to long-term compression atrophy of cerebral cells. The confirmed diagnosis of invasive meningioma should rely on the common decision of imaging examinations, pathological examinations and intraoperative observation. Morphological diagnosis of meningioma relies on MRI and/or CT scan examinations (20).

Results obtained from prior studies showed that usual manifestation of meningioma included uniform density/signal, clear boundary, occasional hemorrhage, necrosis or cystic degeneration and calcification (21). Because of the uneven rate of tumor growth, one of the main characteristics of high invasive meningioma is the mushroom syndrome (22). Another characteristic of high invasive meningioma is the uneven density or signal and heterogeneous enhancement after contrast-enhanced scan. Due to the rapid proliferation rate, the central area of the tumor usually suffers from inadequate blood circulation, which can lead to ischemic necrosis or cystic degeneration. The necrotic area in more invasive tumors is usually larger.
Surgical resection is the preferred treatment for invasive meningioma, however it was previously reported that in $17-50 \%$ of meningioma cases, complete resection cannot be achieved. Therefore, the recurrence rate of meningioma is relatively high (23). Positive correlation among the recurrence rate of meningioma, the degree of malignancy of meningioma and the invasiveness of meningioma has been reported (24). Principle factors affecting the recurrence of meningioma were the biological characteristics of tumor and surgical resection extent (25) (Table IV).

In this study, 18 cases of meningioma with the invasive area of cerebral convexity had Simpson grade I resection. Also, we detected Simpson grade I resection in 4 cases of meningioma with invasion to venous sinus area. In 12 cases, we had Simpson grade II resection. In this study, meningioma invading vascular, nerve and cavernous sinus were identified as WHO grade I, there were 3 cases with Simpson grade II resection and 5 cases with Simpson grade III resection, while we had no case with Simpson grade I resection (Figs. 3 and 4).

In general, during surgeries we did not proceed to complete resection, because in most cases some key structures were invaded and meningioma was very deep and any attempt for total resection could easily lead to significant damage to these structures. In one case we had Simpson grade I resection, however, because tumor cells were already infiltrating the brain tissue, the surgery could not assure avoiding future recurrence. Therefore, surgery could not achieve a full remedy in the case of meningioma with high invasiveness, and postoperative radiotherapy was needed to delay, or prevent the recurrence $(26,27)$.

In conclusion, WHO grade I invasive meningioma was the most common case among our patients, and the course of disease was relatively short. Imaging examinations performed prior to the surgery, played an important role in judging the position and invasiveness of meningioma and the formulation of our surgical plan. Surgical intervention was the preferred method of treatment for invasive meningioma. During the surgery, the comprehensive treatment of the total resection of tumor and invasive dura was conducted, and surgical treatment was combined with postoperative radiotherapy and postoperative follow-up in order to manage the recurrence.

\section{References}

1. Gelabert-González M and Serramito-García R: Intracranial meningiomas: I. Epidemiology, aetiology, pathogenesis and prognostic factors. Rev Neurol 53: 165-172, 2011 (In Spanish).

2. Bondy M and Ligon BL: Epidemiology and etiology of intracranial meningiomas: a review. J Neurooncol 29: 197-205, 1996.

3. Hanft S, Canoll P and Bruce JN: A review of malignant meningiomas: diagnosis, characteristics, and treatment. J Neurooncol 99: 433-443, 2010

4. Rockhill J, Mrugala M and Chamberlain MC: Intracranial meningiomas: an overview of diagnosis and treatment. Neurosurg Focus 23: E1, 2007.

5. Zhang S, Meng H, Gui Y, Chen L, Zhao T, Zhang X, Li G and Yang G: On diagnostics of malignant meningioma and invasive meningioma. Hua Xi Yi Ke Da Xue Xue Bao 27: 192-195, 1996 (In Chinese).

6. Yamazaki T, Takahashi S, Ishii K, Matsumoto K, Ishibashi T, Sakamoto K and Ogawa A: Meningioma in the pineal region: preoperative diagnosis with CT, MRI, and angiography. Radiat Med 9: 22-25, 1991.

7. Chen XR: CT diagnosis of meningioma (analysis of 215 cases). Zhonghua Fang She Xue Za Zhi 20: 292-295, 1986 (In Chinese). 
8. Freeman AC, Platt SR, Kent M and Hofmeister E: What is the evidence? Diagnosis of an intracranial lesion as a meningioma on the basis of MRI characteristics. J Am Vet Med Assoc 239: 60-62, 2011.

9. Huang SQ, Liang BL, Xie BK, Yuan JP, Zhong JL and Ye RX: MRI performance and diagnosis of meningioma - a report of 126 cases. Ai Zheng 23: 1329-1333, 2004.

10. Jain D, Ebrahimi KB, Miller NR and Eberhart CG: Intraorbital meningiomas: a pathologic review using current World Health Organization criteria. Arch Pathol Lab Med 134: 766-770, 2010.

11. Nanda A, Bir SC, Maiti TK, Konar SK, Missios S and Guthikonda B: Relevance of Simpson grading system and recurrence-free survival after surgery for World Health Organization Grade I meningioma. J Neurosurg 126: 201-211, 2017.

12. Fisher JL, Schwartzbaum JA, Wrensch M and Wiemels JL: Epidemiology of brain tumors. Neurol Clin 25: 867-890, 2007.

13. Wrensch M, Minn Y, Chew T, Bondy M and Berger MS: Epidemiology of primary brain tumors: current concepts and review of the literature. Neuro Oncol 4: 278-299, 2002.

14. Huairong L, Peng S and Yaping Z: Detection for single nucleotide polymorphisms. Hereditas 23: 471-476, 2001.

15. Chunxia Z, Xianzhe S and Shen L: Recent advances in single nucleotide polymorphism of human genome research. Chinese J Chromatog 21: 110-114, 2003 (In Chinese).

16. Younis GA, Sawaya R, DeMonte F, Hess KR, Albrecht S and Bruner JM: Aggressive meningeal tumors: review of a series. J Neurosurg 82: 17-27, 1995.

17. Sołtys J, Pietniczka-Załeska M, Młyńczyk-Budzynowska K and Majkowski J: Neoplasms of paranasal sinuses in material of ENT Department MSS Hospital in Warsaw between 2006-2007. Otolaryngol Pol 62: 451-454, 2008 (In Polish).

18. Iaconetta G, Santella A, Friscia M, Abbate V and Califano L Extracranial primary and secondary meningiomas. Int J Oral Maxillofac Surg 41: 211-217, 2012.

19. Yamashima T, Kida S and Yamamoto S: Ultrastructural comparison of arachnoid villi and meningiomas in man. Mod Pathol 1: 224-234, 1988.
20. Daneshi A, Asghari A and Bahramy E: Primary meningioma of the ethmoid sinus: a case report. Ear Nose Throat J 82: 310-311, 2003.

21. Preston DL, Ron E, Yonehara S, Kobuke T, Fujii H, Kishikawa M, Tokunaga M, Tokuoka S and Mabuchi K: Tumors of the nervous system and pituitary gland associated with atomic bomb radiation exposure. J Natl Cancer Inst 94: 1555-1563, 2002.

22. Ron E, Modan B, Boice JD Jr, Alfandary E, Stovall M, Chetrit A and Katz L: Tumors of the brain and nervous system after radiotherapy in childhood. N Engl J Med 319: 1033-1039, 1988.

23. Yamada SM, Yamada S, Takahashi H, Teramoto A and Matsumoto K: Extracranially extended meningothelial meningiomas with a high MIB-1 index: a report of two cases. Neuropathology 24: 66-71, 2004.

24. Lombardi D, Tomenzoli D, Buttà L, Bizzoni A, Farina D, Sberze F, Karligkiotis A, Castelnuovo P and Nicolai P: Limitations and complications of endoscopic surgery for treatment for sinonasal inverted papilloma: a reassessment after 212 cases. Head Neck 33 . 1154-1161, 2011.

25. Busquets JM and Hwang PH: Endoscopic resection of sinonasal inverted papilloma: a meta-analysis. Otolaryngol Head Neck Surg 134: 476-482, 2006.

26. Gotlib T, Osuch-Wójcikiewicz E, Held-Ziółkowska M, Kużmińska M and Niemczyk K: Endoscopic transnasal management of sinonasal malignancies - our initial experience. Wideochir Inne Tech Malo Inwazyjne 9: 131-137, 2014.

27. Lund VJ, Stammberger H, Nicolai P, Castelnuovo P, Beal T, Beham A, Bernal-Sprekelsen M, Braun H, Cappabianca P, Carrau R, et al; European Rhinologic Society Advisory Board on Endoscopic Techniques in the Management of Nose, Paranasal Sinus and Skull Base Tumours: European position paper on endoscopic management of tumours of the nose, paranasal sinuses and skull base. Rhinol 22 (Suppl): 1-143, 2010. 